\title{
IN-CYLINDER FLOW CHARACTERIZATION USING VORTICITY BASED PARAMETERS
}

\section{PETR HATSCHBACH, OLDŘICH VÍTEK, RADEK TICHÁNEK}

Czech Technical University in Prague, Department of Automotive, Combustion Engine and Railway Engineering, Technická 4, 16607 Prague 6, Czech Republic, Tel.: +420224352492, E-mail: petr.hatschbach@fs.cvut.cz

\section{ABSTRACT}

The paper deals with intake swirling flow characterization in the cylinder of IC engine. The commonly used method based on the swirl resp. tumble number from angular momentum flux evaluation does not need to give the appropriate values in some cases. Typically, in the case of two intake ports, a counter-rotating swirl vortex pair is presented. However their summary angular momentum flux is zero a thus corresponding swirl number is zero too. In order to correctly quantify these cases, it is proposed to evaluate so called vorticity numbers, i.e. dimensionless numbers based on vorticity evaluation. Concrete results are evaluated from data obtained using 3-D CFD simulation in AVL FIRE code. Comparison of variously defined vorticity numbers with each other and with the vortex numbers is performed. A practical way of calculating the vorticity numbers was also suggested with regard to possible adverse effects of the velocity gradients at the cylinder wall.

\section{KEYWORDS: IN-CYLINDER FLOW, SWIRL NUMBER, TUMBLE NUMBER, VORTICITY}

\section{SHRNUTí}

Článek se zabývá problematikou kvantifikace úrovně velkých vírových pohybů ve válci spalovacího motoru. Obvykle používaný způsob založený na vyhodnocení vírového čísla swirlu a tumblu z toku momentu hybnosti nemusí v některých prípadech dávat odpovídající hodnoty. Typicky v prípadě dvou sacích kanálů vzniká výrazná dvojice protiběžných vírů, která ale souhrnně má nulový moment hybnosti a tedy i vírové číslo. Aby bylo možné tyto případy správně kvantifikovat, je navrženo vyhodnocovat vírivostní čísla, tj. bezrozměrná čísla založená na vyhodnocení viŕivosti. Konkrétní výsledky jsou dokumentovány na datech získaných pomocí 3-D CFD simulace v programu AVL FIRE. Je provedeno porovnání jednotlivých viŕivostních čísel navzájem i s vírovými čísly. Byl navržen i praktický způsob výpočtu vírivostních čísel s ohledem na možné nepřiznivé ovlivnění velkými rychlostními gradienty u stěny válce. KLIČCOÁ SLOVA: PROUDĚNÍ VE VÁLCI, VÍROVÉ ČISLO, VÍROVÉ ČíSLO TEČNÉ ROTACE, VÍROVÉ ČISLO PŘÍČNÉ ROTACE, VÍR̃IVOST

\section{INTRODUCTION}

Knowledge of gas motion during exchange phase of internal combustion engine (ICE) is very important for optimizing following engine cycle phases - compression and combustion. In-cylinder flow during gas exchange has a significant impact for improving engine combustion performance in terms of large-scale coherent structure formation and in-cylinder turbulence level. In-cylinder flow is very complicated dynamic process, but to make it possible to describe it by the available resources, it is necessary to make some simplifications.

The first simplification consists in the idea of two predominant shapes of the in-cylinder coherent flow structure to swirl and tumble motion - Figure 1. These basic flow structures play an important role due to their ability to maintain turbulence level during compression and enhance mixing of fuel and air.
Determination of swirling motion under conditions of actual engine operation is very demanding and expensive. Experimentally it is feasible only with test engine with optical access by using optical velocity measurement method like LDA or PIV. Full numerical simulation of real in-cylinder flow is very difficult, expensive and time consuming.

Therefore, although in-cylinder flow is a very dynamic process, the second simplification - steady flow testing of cylinder head - is a widely used method in development of engines. Steady flow testing can be done experimentally using a steady flow test rig or by means of numerical simulation.

A non-dimensional parameters called Swirl, resp. Tumble Number are used for swirl or tumble level characterization. Unfortunately no standard testing methodology currently exists. 

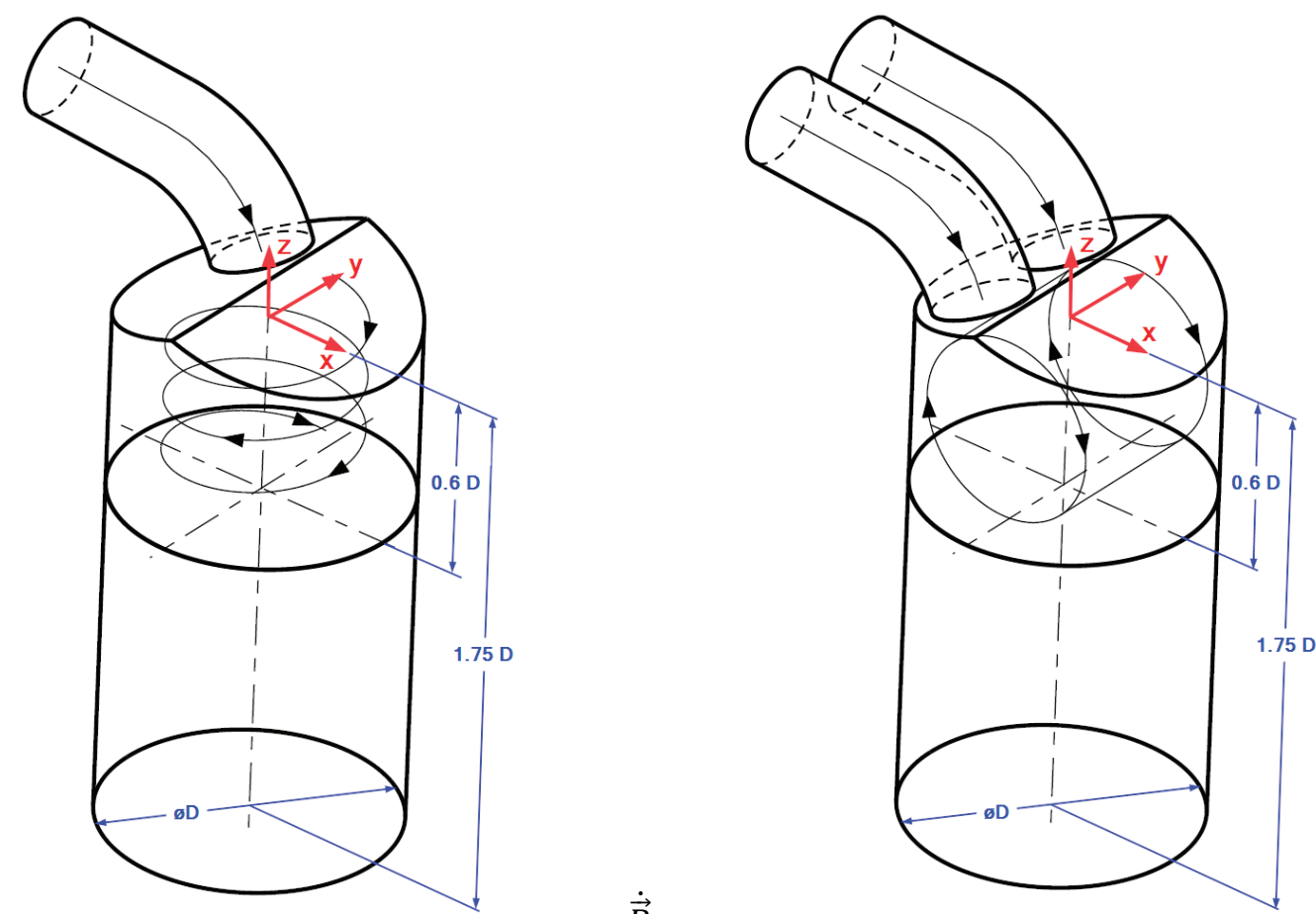

FIGURE 1: Swirl and Tumble - single opened port and both opened ports cases - coordinate systems and position evaluation planes OBRÁZEK 2: Swirl a tumble - varianty jednoho a obou otevřených kanálü - souřadný systém a poloha vyhodnocovacích rovin

Angular momentum flux based definitions of swirl or tumble number are more commonly used. However in some cases their use may give obviously misleading results.

Therefore new non-dimensional parameters based on vorticity evaluation were proposed. Three different parameters are defined in the present article and their use is compared on two typical examples of in-cylinder flow. These examples also show that it is a very important how these parameters are evaluated.

\section{ANGULAR MOMENTUM FLUX BASED PARAMETERS}

In-cylinder swirling flow is most often characterized by the angular momentum of cylinder charge. During the steady flow test, you can evaluate (or measure) the angular momentum flux in some cross section area in the engine cylinder:

$$
\dot{\vec{B}}=\int_{\mathrm{A}}(\vec{r} \times \varrho \vec{u}) \vec{u} \cdot d A
$$

where: $Q \ldots$.. density, $r$... position vector, $\vec{u} \ldots$ velocity vector, A ... cross section area.

Displacement of the cross section corresponds to the position of the measurement element during swirl or tumble measurement. In both cases, cross section is a circular area, perpendicular to the $z$-axis, $D \ldots$ diameter $=$ cylinder bore. For the honeycomb torque meter used for the swirl measurement, displacement is $1.75 D$ ( $D$... diameter $=$ cylinder bore), for tumble measurement by means original CTU tumble meter [1], displacement is $0.6 \mathrm{D}$. Swirl is characterized by swirl- i.e. z-component of angular momentum flux $\dot{\vec{B}}$ :

$\dot{B}_{S}=\dot{B}_{z}=\int_{A}\left(x \cdot u_{y}-y \cdot u_{x}\right) \varrho u_{z} d A$

For tumble characterization it is necessary to merge $x$ and $y$ component of angular momentum flux $\vec{B}$ :

$$
\begin{aligned}
& \dot{B}_{x}=\int_{A} y \varrho u_{z}^{2} d A \quad \dot{B}_{y}=-\int_{A} x \varrho u_{z}^{2} d A \\
& \dot{B}_{T}=\sqrt{\dot{B}_{x}^{2}+\dot{B}_{y}^{2}}
\end{aligned}
$$

Angular momentum flux components $\dot{B}_{S}$ and $\dot{B}_{T}$ can be measured or evaluated from CFD simulations. In this case, integrals must be evaluated numerically as sums.

Supposing that the cylinder charge is a solid rotating body, we can express angular momentum flux:

$\dot{B}=\dot{I} . \omega=\dot{m} r_{I}^{2} . \omega$ 
where: $\dot{I} . .$. moment of inertia flux,$\omega \ldots$ angular speed of solid body, $\dot{m}$... mass flow rate, $r_{I} \ldots$ radius of gyration $\left(r_{I}^{2}=D^{2} / 8\right.$ for circular cylinder or disc about its axis).

The angular speed of charge equivalent solid body rotation for swirl and tumble are:

$\omega_{S}=\frac{8 \cdot \dot{B_{S}}}{\dot{m} \cdot D^{2}} \quad \omega_{T}=\frac{8 \cdot \dot{B_{T}}}{\dot{m} \cdot D^{2}}$

Non-dimensional swirling parameters are defined as ratio between vortex angular speed and fictitious engine angular speed $\omega_{e}$. Engine angular speed can be expressed from the equation for the mean piston speed $u_{z \text { mean }}$ - after some modifications:

$u_{z \text { mean }}=2 Z n_{e} \quad u_{z \text { mean }}=\frac{\dot{m}}{\rho \frac{\pi D^{2}}{4}} \quad \omega_{e}=2 \pi n_{e}$

$\omega_{e}=\frac{4 \cdot \dot{m}}{\rho \cdot D^{2} \cdot Z}$

where: $n_{e} \ldots$ crankshaft rotational speed [1/s], Z... stroke.

Rewriting the equations (6) and (8) the swirl and tumble number can be expressed as:

$S N=\frac{\omega_{S}}{\omega_{e}}=\frac{2 \cdot Z \cdot \rho \cdot \dot{B}_{S}}{\dot{m}^{2}}$

$T N=\frac{\omega_{T}}{\omega_{e}}=\frac{2 \cdot Z \cdot \rho \cdot \dot{B}_{T}}{\dot{m}^{2}}$

For better comparison of results between different engines (in terms of design), a reduced swirl and tumble numbers are defined:

$S N_{r}=S N \cdot \frac{D}{Z}=\frac{2 \cdot D \cdot \rho \cdot \dot{B}_{S}}{\dot{m}^{2}}$

$T N_{r}=T N \cdot \frac{D}{Z}=\frac{2 \cdot D \cdot \rho \cdot \dot{B}_{T}}{\dot{m}^{2}}$

This definition reduces the above-mentioned swirl and tumble numbers to the case of engine with 'square' design (bore equals stroke). Reduced numbers do not have in terms of steady test a misleading dependence on the stroke $Z$.

\section{VORTICITY BASED PARAMETERS}

Vorticity $\vec{\omega}$ describes a local value of fluid rotation in the target plane. For example, for swirl characterization is important $z$-component of vorticity in $z=$ const plane:

$\omega_{z}=\frac{\partial u_{y}}{\partial x}-\frac{\partial u_{x}}{\partial y}$
The vorticity was used to characterize in-cylinder swirling flow in works [2] [3]. In [2] the velocity and vorticity field in plane area was only qualitatively monitored, in [3] were defined equations for computing average, absolute and RMS circulations about an enclosed contour. Integral parameters average, absolute and RMS vorticity were defined in [4]. These definitions are also suitable for evaluation on irregular meshes.

Non-dimensional parameters based on vorticity evaluation were defined in [5]. But those parameters are not very well named, because terms swirl and tumble ratios are often used for non-dimensional weighted sum of the angular momentum introduced to the cylinder during the whole intake phase.

This paper defines three dimensionless parameters based on three methods of mean vorticity evaluating:

- AVG swirl vorticity number $V N_{z A V G}$ computed from AVG vorticity $\omega_{z A V G}$ calculated as area weighted mean z-component of vorticity:

$V N_{z A V G}=\frac{\omega_{z A V G}}{2 . \omega_{e}}$

$\omega_{z A V G}=\frac{1}{A} \int_{A}\left(\frac{\partial u_{y}}{\partial x}-\frac{\partial u_{x}}{\partial y}\right) d A$

ABS swirl vorticity number $V N_{z A B S}$ computed from mean vorticity $\omega_{z A B S}$ calculated as area weighted absoluted value z-component of vorticity:

$V N_{z A B S}=\frac{\omega_{z A B S}}{2 . \omega_{e}}$

$\omega_{z A B S}=\frac{1}{A} \int_{A}\left|\frac{\partial u_{y}}{\partial x}-\frac{\partial u_{x}}{\partial y}\right| d A$

RMS swirl vorticity number $V N_{z} R M S$ computed from mean vorticity $\omega_{z \text { RMS }}$ calculated as area weighted root mean square value $z$-component of vorticity:

$V N_{z R M S}=\frac{\omega_{z R M S}}{2 . \omega_{e}}$

$\omega_{z R M S}=\sqrt{\frac{1}{A} \int_{A}\left(\frac{\partial u_{y}}{\partial x}-\frac{\partial u_{x}}{\partial y}\right)^{2} d A}$

Definition of AVG vorticity number corresponds to the definition of swirl or tumble ratio in [5].

$A B S$ vorticity number can only be positive because it is calculated only from the absolute values of the partial vorticities. Each 
microscopic circulation contributes positively to the total sum. It is believed that this definition could be applicable to the overall quantification e.g. two counter-rotating vortex structures.

RMS-vorticity number will be qualitative similar to $A B S$ vorticity number, but large vorticities will have a larger weight due to the calculation with quadrate of vorticity.

For swirling flow like a rotating rigid body, vorticity $\omega_{z}$ in each point of $z=$ const area and mean vorticity $\omega_{z A V G}$ (and absoluted vorticity $\omega_{z A B S}$ too) have a same constant value equal to twice the angular velocity of rotating flow.

\section{COMPUTED CASES AND METHOD OF EVALUATION}

The results of simulations of steady flow test bench described in work [6] and other newly calculated results were used for comparison in the previous part described non-dimensional parameters. These are the results of intake port steady flow bench simulation of 4-valve SI engine (bore $76.5 \mathrm{~mm}$ ). Two different cases were calculated: both intake valves are open (classical configuration, typical for SI engine, tumble dominated flow pattern) and single intake valve is open (unconventional, swirl dominated flow pattern). The valve lift was set from 1 to $9 \mathrm{~mm}$.

Flow field was calculated by means of 3D CFD code AVL FIRE. PANS turbulence model, 4 boundary layers with $0.15 \mathrm{~mm}$ boundary layer thickness and unsteady simulation mode were used (up to time $0.160 \mathrm{~s}$ with step $0.00001 \mathrm{~s}$ ). Boundary conditions correspond to steady flow test bench measurement setup - the most important one is the pressure difference between inlet and outlet was constant at the value of $5 \mathrm{kPa}$. More details about the calculation settings are described in [6].

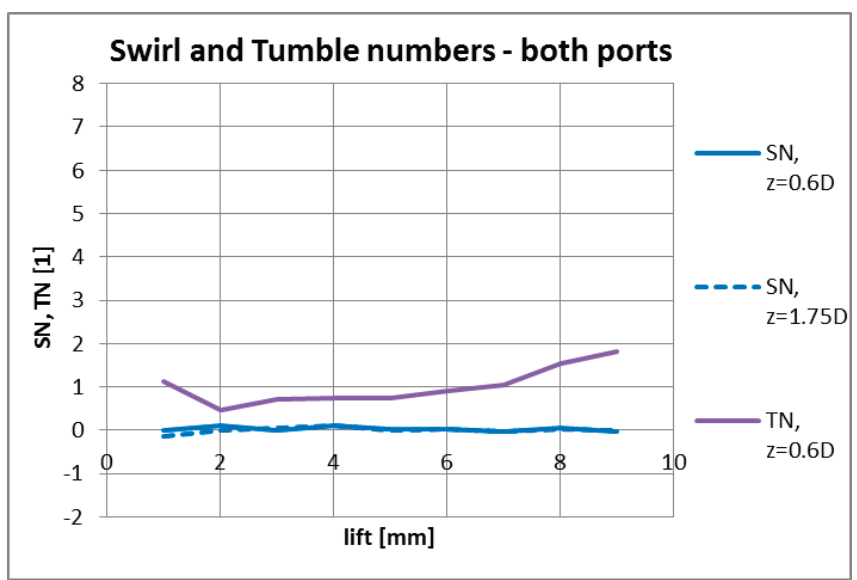

FIGURE 2: Swirl and Tumble number - dependence on valve lift - the case of both intake valves being opened.

OBRÁZEK 2: Vírová čísla swirlu a tumblu - závislost na zdvihu ventilu varianta se dvěma otevřenými sacími ventily.
Swirl and vorticity numbers were evaluated in planes placed 0.6 or 1.75 bore diameter respectively away from the cylinder head. These distances correspond to the location of the CTU tumble meter or honeycomb swirl meter. AVL FIRE command-line tool fire_utils_integrate was used to integrate CFD results over appropriate cell selection [7]. Subsequent evaluation was performed in the MS Excel spreadsheet.

\section{RESULTS AND DISCUSSION}

Evaluation of swirl and tumble number depending on valve lift is the usual method of large vortex movements' characterization. The case of both intake valve opened is shown in Figure 2. Tumble is dominant shape of the in-cylinder flow structure. The case of single intake valve opened is shown in Figure 3. Swirl is expected here as the main vortex shape. It is possible to make these conclusions:

- Swirl number in the case of both valve opened is practically zero. Only tumble number is evaluable.

- In the case of single valve opened it is possible to evaluate both swirl and tumble. Both swirl and tumble number curves have the similar quantity and trend.

- Relative level of large vortex structure in the case of both opened valves is always less than for single open valve case.

- Swirl number decreases slightly with the distance from the cylinder head.

Further evaluations will focus on the swirl in-cylinder motion. In Figure 4, 5, 6 and 7 are shown velocity and vorticity fields in distances $0.6 \mathrm{D}$ and $1.75 \mathrm{D}$ from cylinder head and for both cases of valve opening.

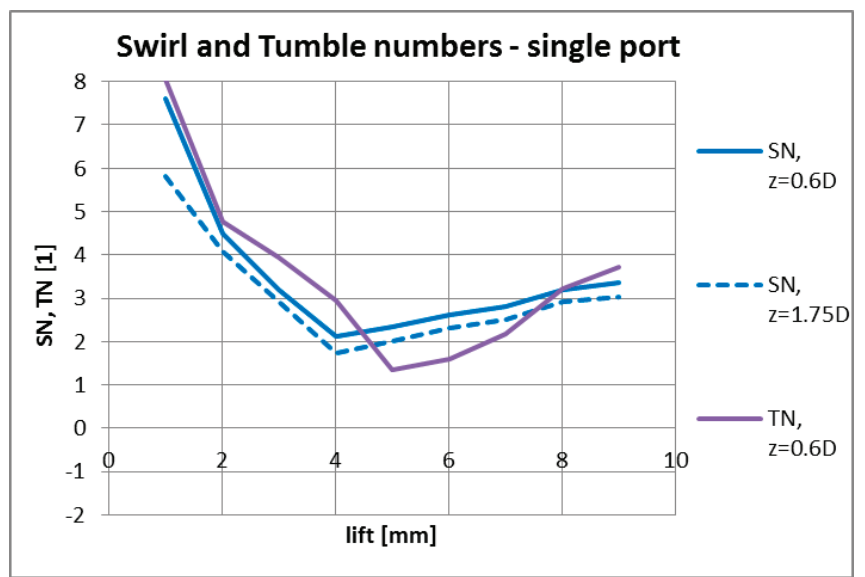

FIGURE 3: Swirl and Tumble number - dependence on valve lift - the case of single intake valve being opened.

OBRÁZEK 3: Vírová čísla swirlu a tumblu - závislost na zdvihu ventilu varianta s jedním otevřeným sacím ventilem. 
It can be seen that in the case of both valves opened - Figure 4 and 5, significant counter-rotating vortex pair is presented. However the swirl number SN, calculated from the angular momentum flux according to (9), is practically zero for all valve lift values. This is due to the fact that both swirl structures are approximately identical but counter-rotating, so that the angular momentum flux is virtually zero. Therefore, it is clear that the quantitative evaluation using the swirl number does not correspond to reality in these cases.

Because of their opposite orientation, both vortex will interact, slow down and gradually collapse into smaller vortex and chaotic turbulence in the intake stroke and early compression stroke. Just by comparing the velocity fields in distances $0.6 \mathrm{D}$ and $1.75 \mathrm{D}$ it is obvious that the vortex decay will be faster in the case of two counter-rotating vortices (both valve opened) than in case of single valve opened, when a single large vortex is created and filling the entire space of cross section. However, they certainly represent a significant part of the large vortex movements and should be considered.

A possible way to quantify the vortex level in these cases is to use appropriately defined vorticity numbers. The dependency of $A V G, A B S$ and RMS vorticity number on valve lift is presented in Figure 8, 9 and 10 for cases of integration by formulas (14), (15) and (16) respectively. Vorticity numbers are evaluated in distances $0.6 \mathrm{D}$ and $1.75 \mathrm{D}$ and in circular area having 4 different diameters: $76.5 \mathrm{~mm}$ (the entire cylinder cross section), $76 \mathrm{~mm}, 74 \mathrm{~mm}$ and $72 \mathrm{~mm}$. The case of both opened valvesi on the left, the case of single opened valve is on the right.

The first interesting conclusion follows from the chart of AVG vorticity number in Figure 8. AVG vorticity number is equal to zero when computed across the entire cross-section ( $D=76.5 \mathrm{~mm}$ ). This is in conformity with the Green's theorem, which describes a relationship between the macroscopic circulation around closed curve and the sum of all the microscopic circulation that is inside this curve. We can write integral in formula (14) as:

$$
\int_{A}\left(\frac{\partial u_{y}}{\partial x}-\frac{\partial u_{x}}{\partial y}\right) d A=\oint_{\partial A} \vec{u} \cdot d \partial A=0
$$

and this integral is equal zero because of the zero fluid velocity $\vec{u}$ at the wall.

The second conclusion follows from Figure 8 left. For case of both intake ports opened the AVG vorticity number oscillates around zero. Therefore AVG vorticity number is not able to capture the effect of two counter-rotating vortices - like classical swirl number computed from angular momentum flux The third note is concerning the method of practical evaluation of the vorticity number. In the practical evaluation of the vorticity numbers, it is necessary to deal with the problem related to the calculation of the respective component of the vorticity vector by the difference of the two partial derivations (13). In the area of large velocity gradients, the vorticity evaluation may be subject to large uncertainty, since actually two large numbers, calculated as a proportion of a large and a small number, are subtracted. This fact causes a further increase in the uncertainty of determining vorticity beyond the usual uncertainty in the numerical calculation of the derivative. Because large velocity gradients are usually only in the wall boundary layers with decreasing flow velocity, their real contribution to the quantification of large vortex structure (in terms of influence on angular momentum flux value) is small, insignificant. However, these large gradients have a big influence on the value of vorticity and vorticity numbers.

A possible solution is to exclude the area of the wall boundary layer in the evaluation. The gradual reduction of the influence of vorticity evaluated in the wall boundary layer to vorticity number was monitored - Figure 8, 9 and 10. Vorticity numbers evaluated from area without the wall boundary layer (diameter $76 \mathrm{~mm}$ and lower) are almost equal. Practical evaluation of the vorticity numbers is therefore appropriate to calculate in the area reduced by about $1 \%$ of the cylinder diameter.

\section{CONCLUSION}

The commonly used swirl and tumble number based on angular momentum flux evaluation fail to characterize the level of swirling movements in some cases - for example in case of counter-rotating swirl vortex pair added to dominant tumble motion. Proposed vorticity number can solved this problem because they characterize level of microscopic vortex structure on the scale corresponding to the evaluation mesh size.

However AVG vorticity number calculated as simple sum of appropriate vorticity component provides similar results like from angular momentum flux computed swirl number because it respects rotation direction too. ABS and RMS vorticity number responds correctly, as has been demonstrated by evaluating of two typical in-cylinder flow cases. It is probably more convenient to use the ABS vorticity number because the RMS vorticity number is calculated as the quadratic mean and thus overestimates larger vortices.

Vorticity number can be used as an auxiliary parameter to refine the characterization of intake swirling flow, for example as a correction factor to the standard swirl and tumble numbers. This is especially important in cases when there are two counter-rotating swirl vortices. The way to include vorticity number in the computational models will be the subject of further work. 
Both ports, $z=0.6 \mathrm{D}$

$1 \mathrm{~mm}$

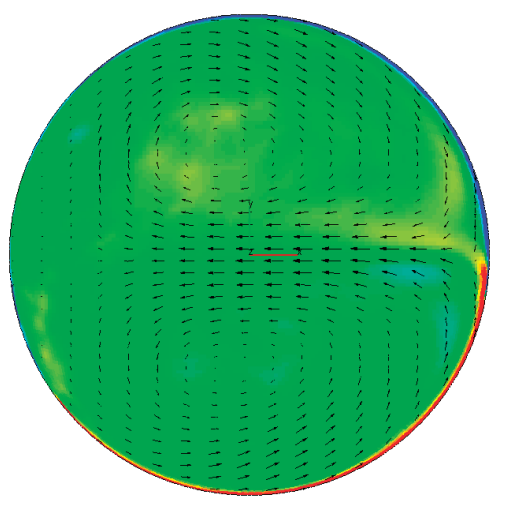

$\mathrm{SN}=0.01 \quad \mathrm{VN}_{\mathrm{zABS}}=7.75$

$4 \mathrm{~mm}$

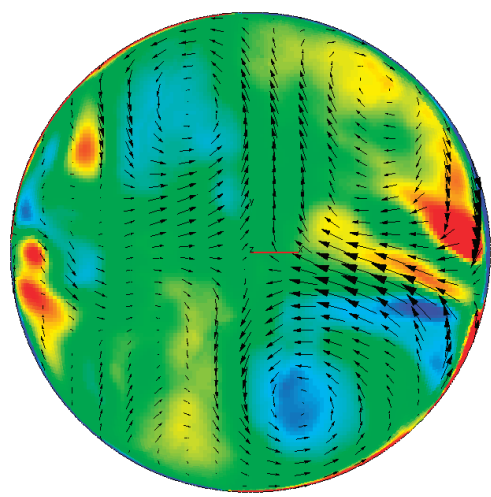

$\mathrm{SN}={ }_{0} .12$

$7 \mathrm{~mm}$

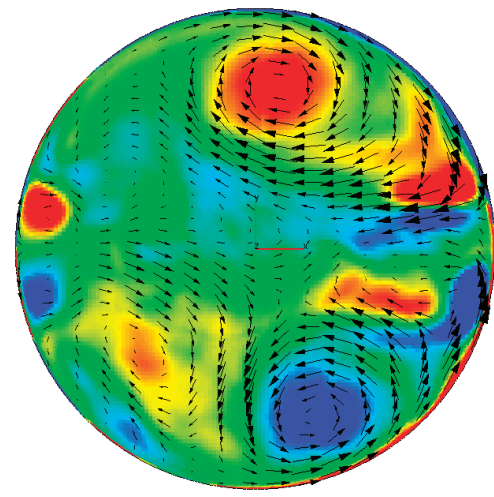

$\mathrm{SN}=0.04 \quad \mathrm{VN}_{\mathrm{zABS}}=2.70$

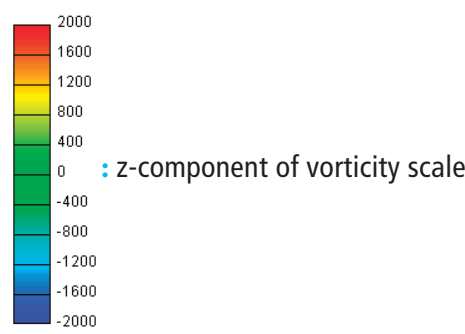

$2 \mathrm{~mm}$

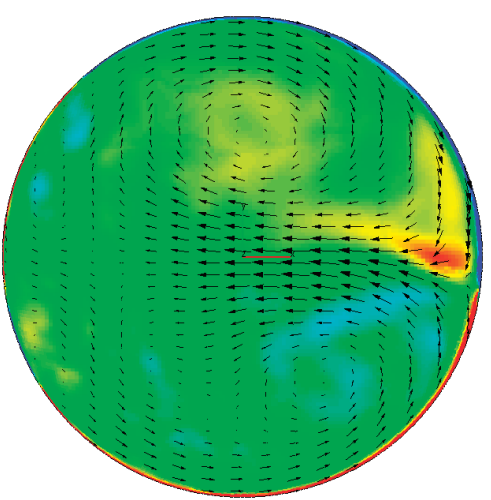

$\mathrm{SN}=0.11$

$5 \mathrm{~mm}$

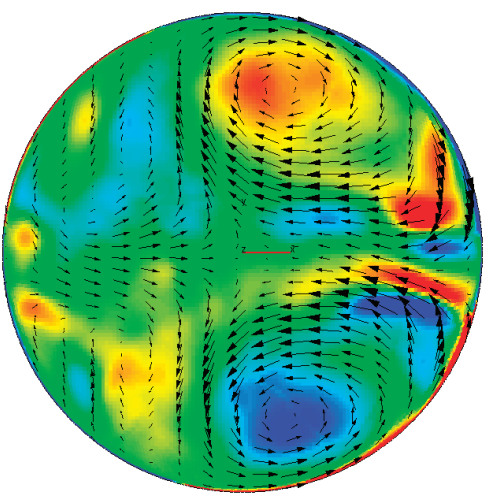

$\mathrm{SN}=0.03 \quad \mathrm{VN}_{\mathrm{zABS}}=3.21$

$8 \mathrm{~mm}$

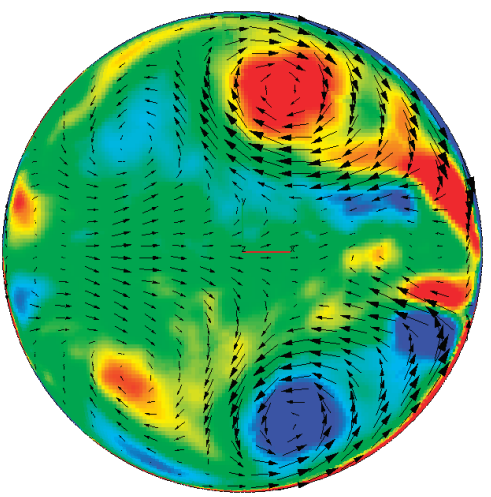

$\mathrm{SN}=0.04 \quad \mathrm{VN}_{\mathrm{zABS}}=2.88$

FIGURE 4: Velocity vector field and vorticity z-component (color scale) + swirl number and ABS swirl vorticity number - distance $0.6 \mathrm{D}$ from cylinder head, dependence on valve lift - both intake valves being opened

OBRÁZEK 4: Pole vektorů rychlosti a z-ové složky viríivosti + vírové číslo swirlu a ABS vírivostní číslo swirlu - vzdálenost $0.6 \mathrm{D}$ od hlavy válce, závislost na zdvihu ventilu - otevřené oba sací ventily. 
Both ports, $z=1.75 \mathrm{D}$

$1 \mathrm{~mm}$

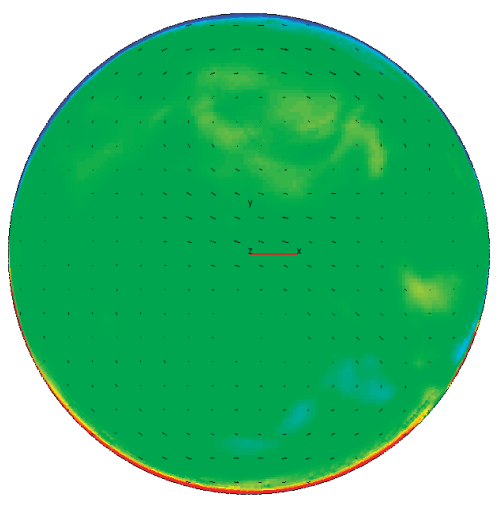

$\mathrm{SN}=-0.15 \quad \mathrm{VN}_{\mathrm{zABS}}=3.93$

$4 \mathrm{~mm}$

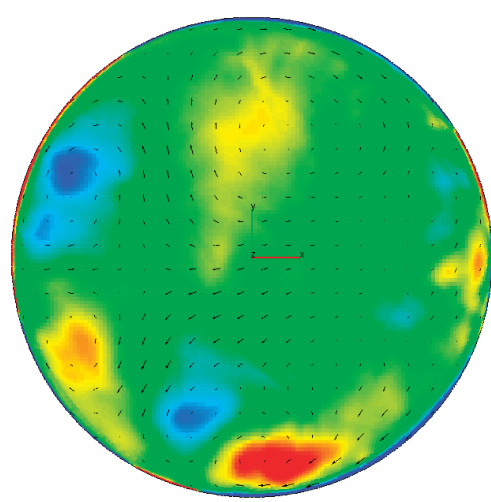

$\mathrm{SN}=0.11$

$\mathrm{VN}_{\mathrm{zABS}}=1.70$

$7 \mathrm{~mm}$

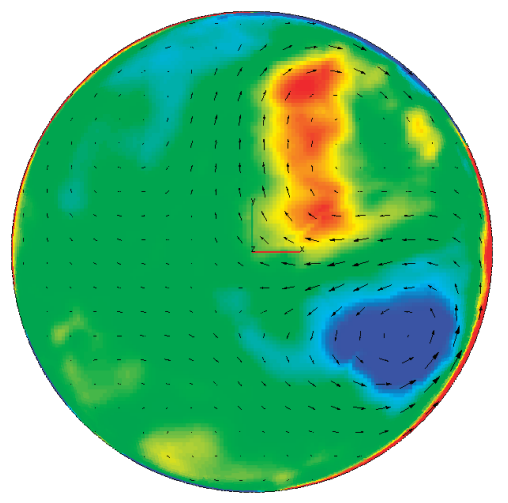

$\mathrm{SN}=-0.04 \quad \mathrm{VN}_{\mathrm{zABS}}=1.26$
$2 \mathrm{~mm}$

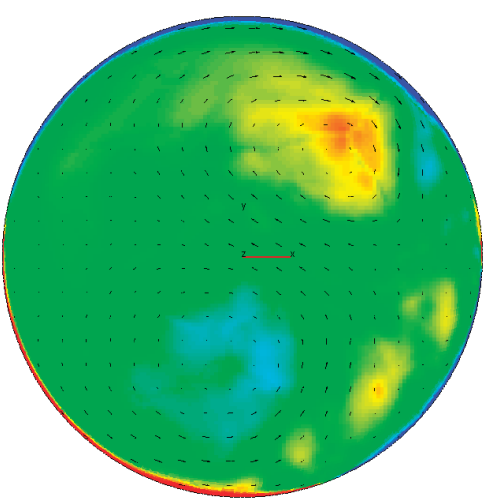

SN $=-0.01$

$\mathrm{VN}_{\mathrm{zABS}}=2.53$

$5 \mathrm{~mm}$

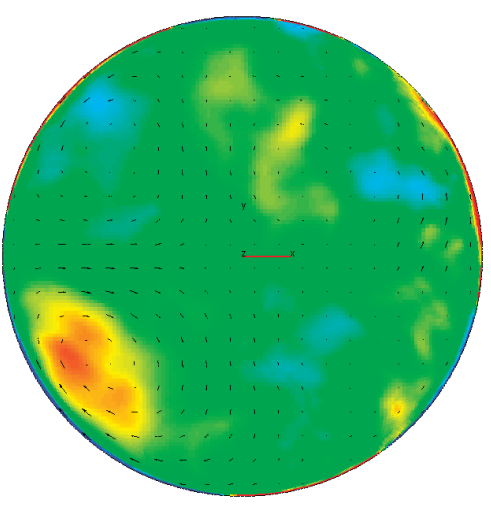

$\mathrm{SN}=-0.01 \quad \mathrm{VN}_{\mathrm{zABS}}=1.49$

$8 \mathrm{~mm}$

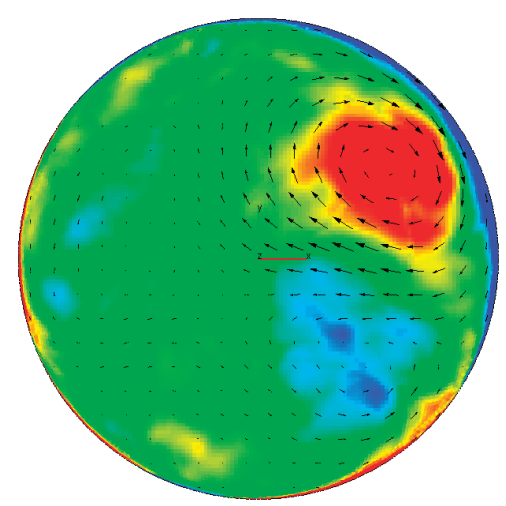

$\mathrm{SN}=0.02 \quad \mathrm{VN}_{\mathrm{zABS}}=1.30$ $\stackrel{0}{\stackrel{50}{\mathrm{~m} / \mathrm{s}}} \stackrel{50}{=}$ velocity scale

$3 \mathrm{~mm}$

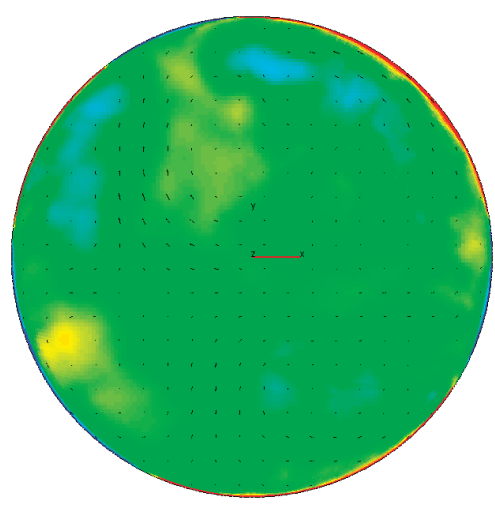

$\mathrm{SN}=0.04 \quad \mathrm{VN}_{\mathrm{zABS}}=1.86$

$6 \mathrm{~mm}$

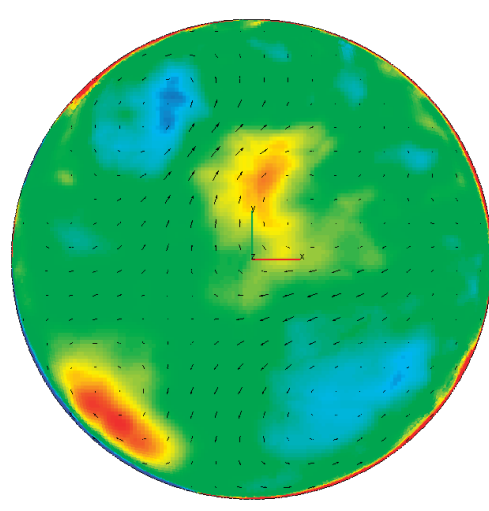

$\mathrm{SN}=0.02 \quad \mathrm{VN}_{\mathrm{zABS}}=1.42$

$9 \mathrm{~mm}$

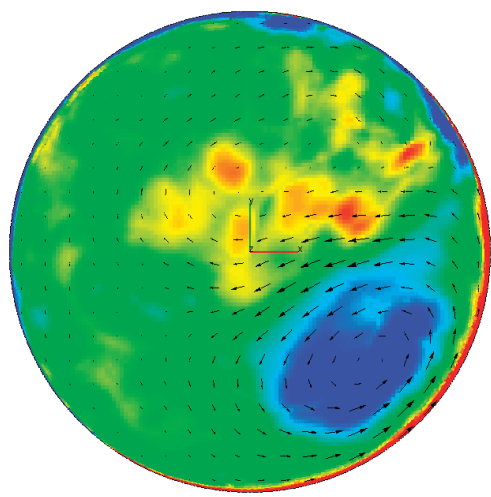

$\mathrm{SN}=0.00 \quad \mathrm{VN}_{\mathrm{zABS}}=1.39$

FIGURE 5: Velocity vector field and vorticity z-component (color scale) + swirl number and ABS swirl vorticity number - distance 1.75D from cylinder head, dependence on valve lift - both intake valves being opened

OBRÁZEK 5: Pole vektorů rychlosti a z-ové složky viririvosti + vírové číslo swirlu a ABS viríivostní číslo swirlu - vzdálenost 1.75D od hlavy válce, závislost na zdvihu ventilu - otevřené oba sací ventily. 
Single port, $z=0.6 \mathrm{D}$

$1 \mathrm{~mm}$

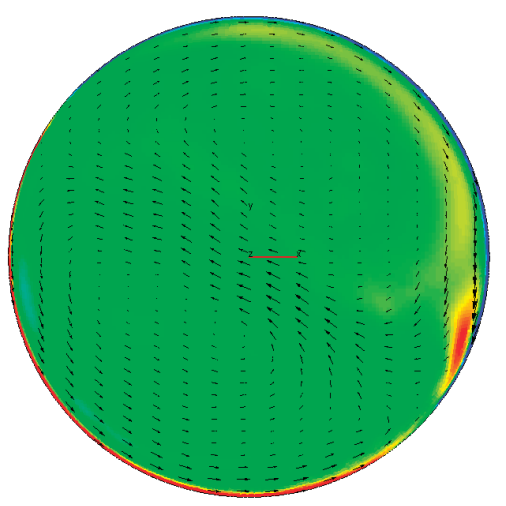

$\mathrm{SN}=7.61 \quad \mathrm{VN}_{\mathrm{zABS}}=10.94$

$4 \mathrm{~mm}$

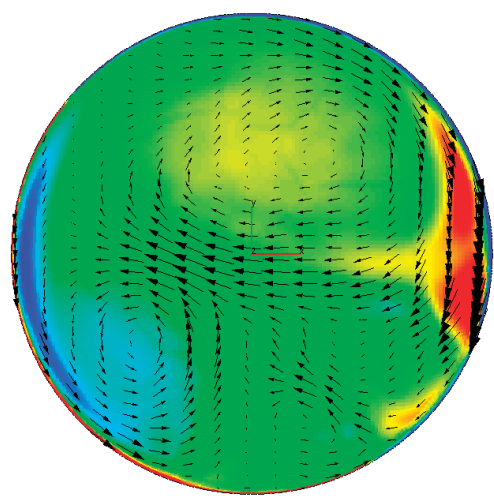

$\mathrm{SN}=2,13$

$7 \mathrm{~mm}$

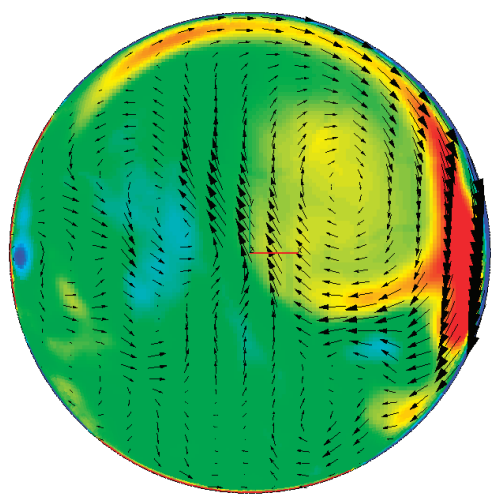

$\mathrm{SN}=2,81$

$\mathrm{VN}_{\mathrm{zABS}}=3.94$

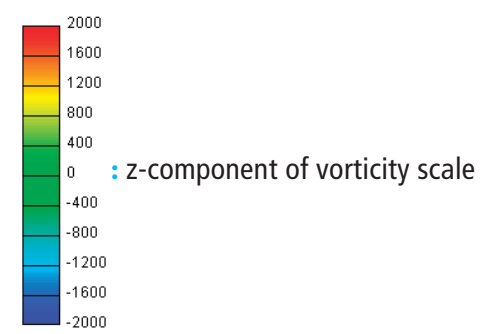

$2 \mathrm{~mm}$

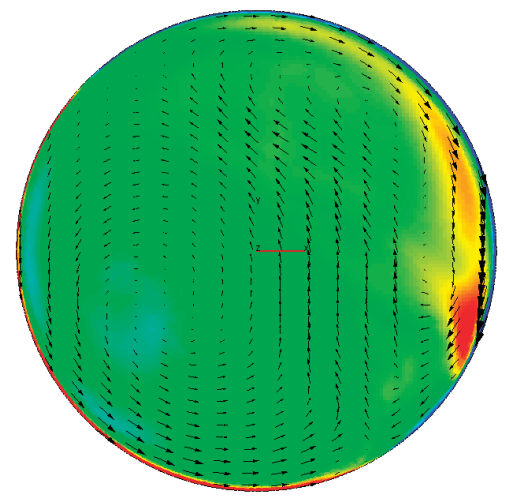

$\mathrm{SN}=4.50$

$5 \mathrm{~mm}$

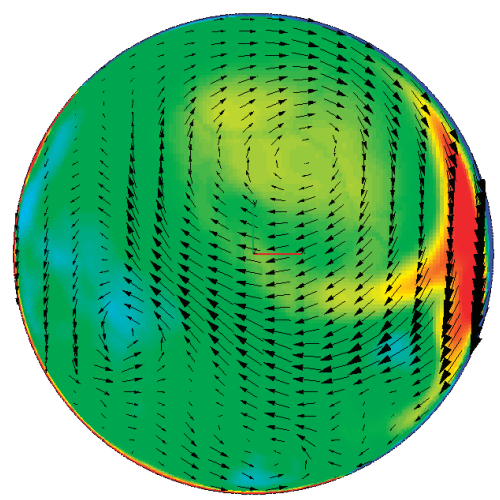

$\mathrm{SN}=2,33 \quad \mathrm{VN}_{\mathrm{zABS}}=4.28$

$8 \mathrm{~mm}$

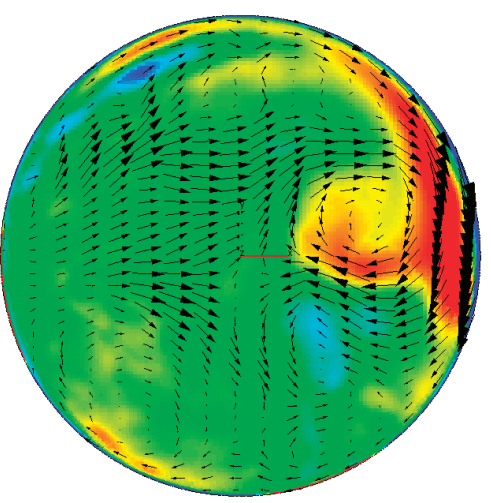

$\mathrm{SN}=3,20 \quad \mathrm{VN}_{\mathrm{zABS}}=4.23$ $\stackrel{0}{\mathrm{~m} / \mathrm{s}} \stackrel{50}{-}$ : velocity scale

$3 \mathrm{~mm}$

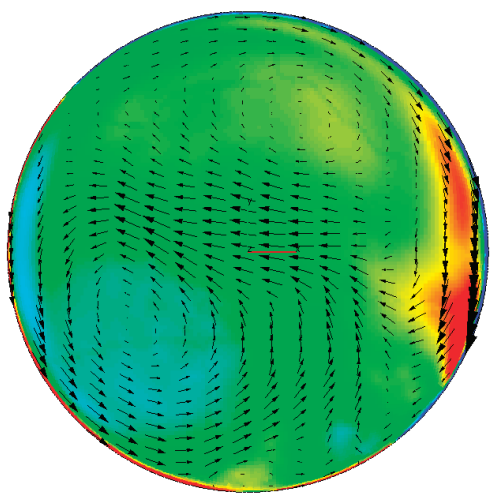

$\mathrm{SN}=3.21 \quad \mathrm{VN}_{\mathrm{zABS}}=5,44$

$6 \mathrm{~mm}$

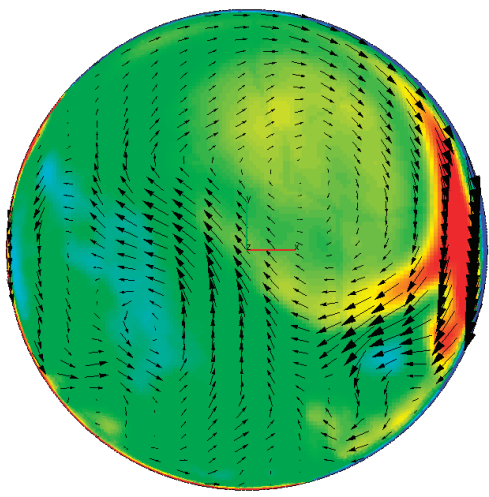

$\mathrm{SN}=2,62 \quad \mathrm{VN}_{\mathrm{zABS}}=4.10$

$9 \mathrm{~mm}$

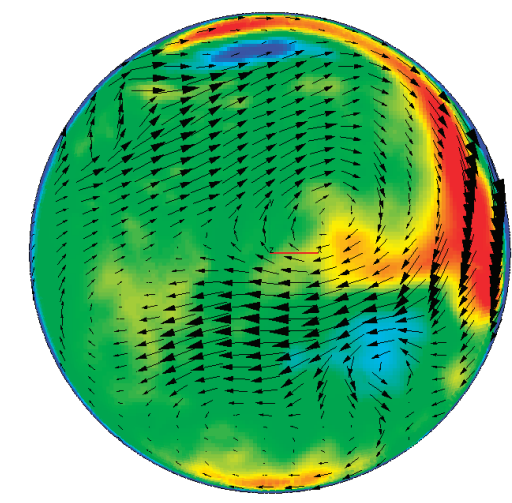

$\mathrm{SN}=3,35 \quad \mathrm{VN}_{\mathrm{zABS}}=4.44$

FIGURE 6: Velocity vector field and vorticity z-component (color scale) + swirl number and ABS swirl vorticity number - distance $0.6 \mathrm{D}$ from cylinder head, dependence on valve lift - single intake valve being opened.

OBRÁZEK 6: Pole vektorů rychlosti a z-ové složky viríivosti + vírové číslo swirlu a ABS viríivostní číslo swirlu - vzdálenost $0.6 \mathrm{D}$ od hlavy válce, závislost na zdvihu ventilu - otevřený jeden sací ventil. 
Single port, $z=1.75 \mathrm{D}$

$1 \mathrm{~mm}$

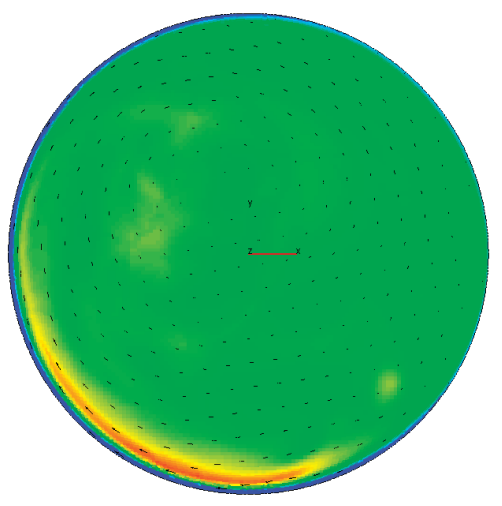

$\mathrm{SN}=5.81 \quad \mathrm{VN}_{\mathrm{zABS}}=5.58$

$4 \mathrm{~mm}$

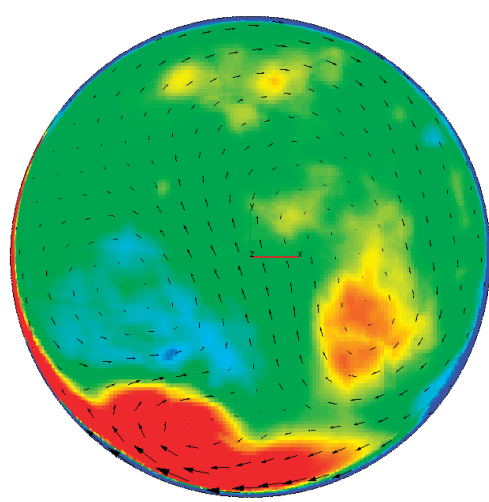

$\mathrm{SN}=1.73$

$\mathrm{VN}_{\mathrm{zABS}}=3.74$

$7 \mathrm{~mm}$

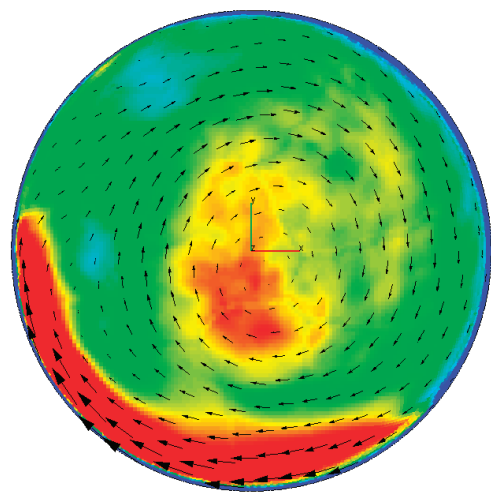

$\mathrm{SN}=2.50$

$\mathrm{VN}_{\mathrm{zABS}}=2.71$
$2 \mathrm{~mm}$

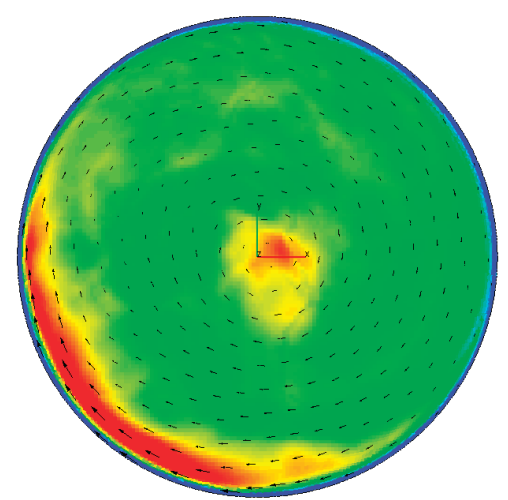

$\mathrm{SN}=4.08$

$5 \mathrm{~mm}$

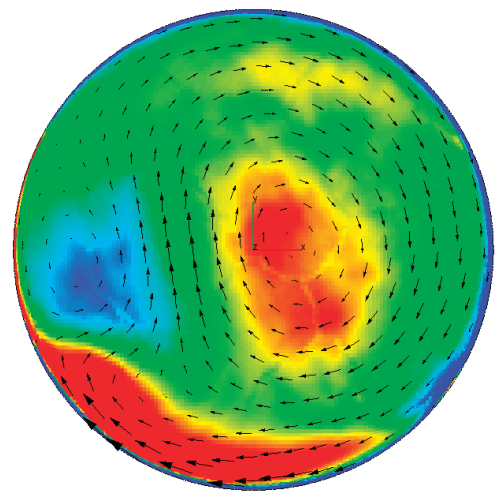

$\mathrm{SN}=2.02$

$\mathrm{VN}_{\mathrm{zABS}}=3.51$

$8 \mathrm{~mm}$

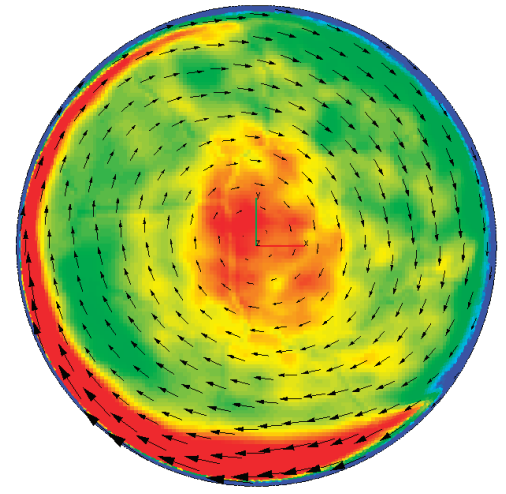

$\mathrm{SN}=2.91$

$\mathrm{VN}_{\mathrm{zABS}}=2.84$ $\stackrel{0}{\mathrm{~m} / \mathrm{s}} \stackrel{50}{=}$ : velocity scale

$3 \mathrm{~mm}$

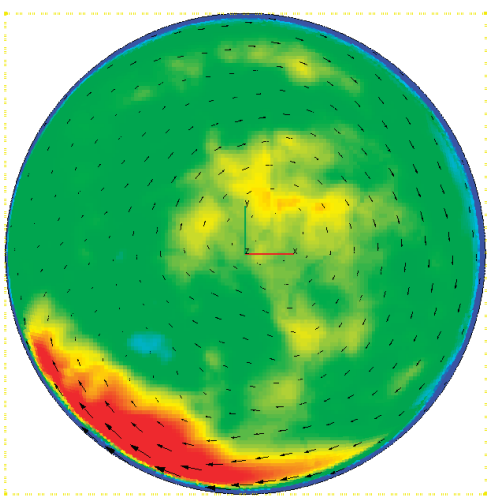

$\mathrm{SN}=2.92 \quad \mathrm{VN}_{\mathrm{zABS}}=4.68$

$6 \mathrm{~mm}$

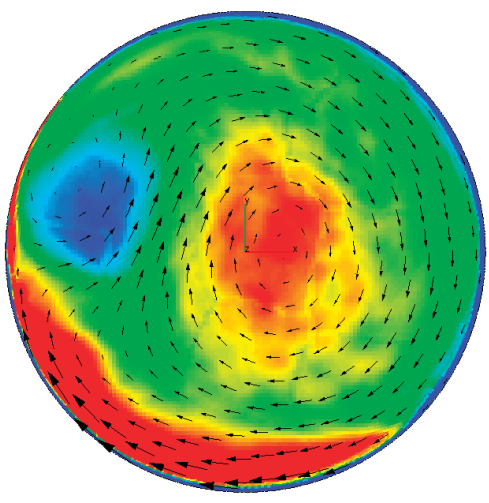

$\mathrm{SN}=2.31 \quad \mathrm{VN}_{\mathrm{zABS}}=3.42$

$9 \mathrm{~mm}$

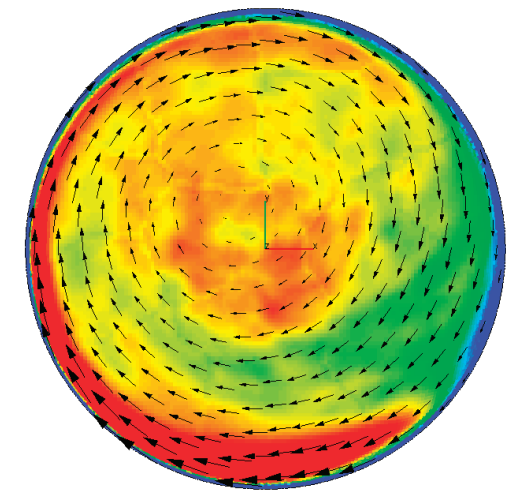

$\mathrm{SN}=3.04 \quad \mathrm{VN}_{\mathrm{zABS}}=2.78$

FIGURE 7: Velocity vector field and vorticity z-component (color scale) + swirl number and ABS swirl vorticity number - distance 1.75D from cylinder head, dependence on valve lift - single intake valve being opened.

OBRÁZEK 7: Pole vektorů rychlosti a z-ové složky vírivosti + vírové čislo swirlu a ABS vírivostní číslo swirlu - vzdálenost 1.75D od hlavy válce, závislost na zdvihu ventilu - otevřený jeden sací ventil. 

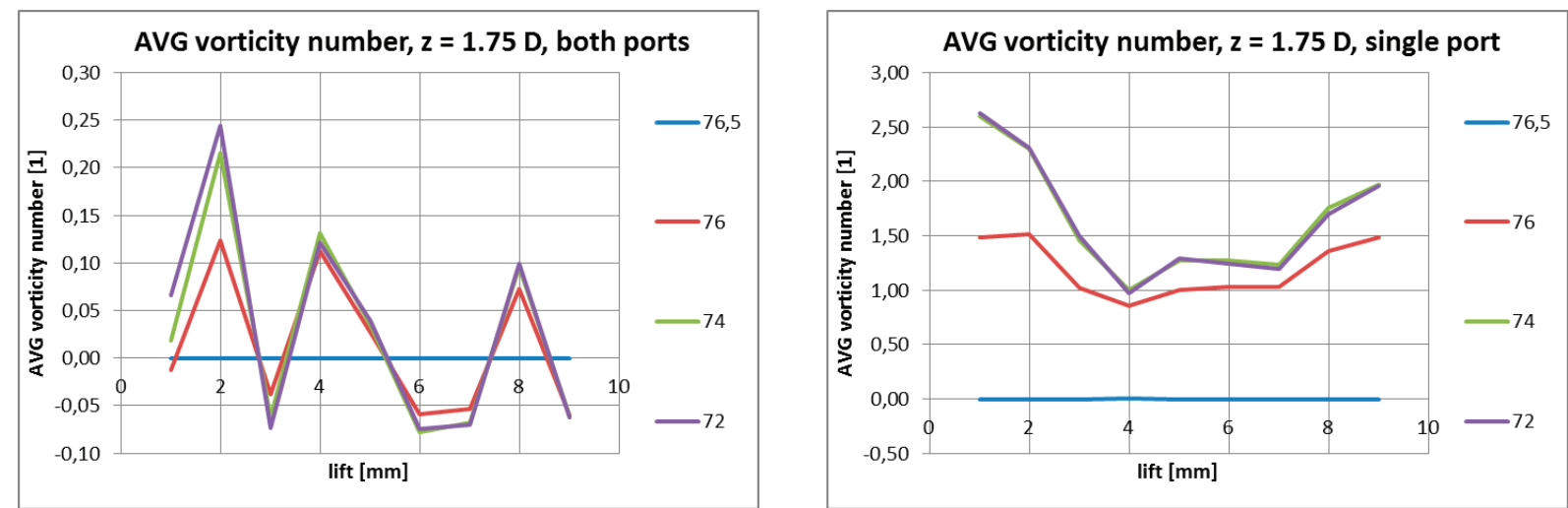

FIGURE 8: AVG swirl vorticity number - dependence on valve lift and max. diameter of evaluation area - the case with both open intake valves is on the left, the case with single open valve is on the right.

OBRÁZEK 8: AVG viŕivostní číslo - závislost na zdvihu ventilu a max. průměru vyhodnocovací oblasti - varianta se dvěma otevřenými sacími ventily vlevo, s jedním otevřeným ventilem vpravo.
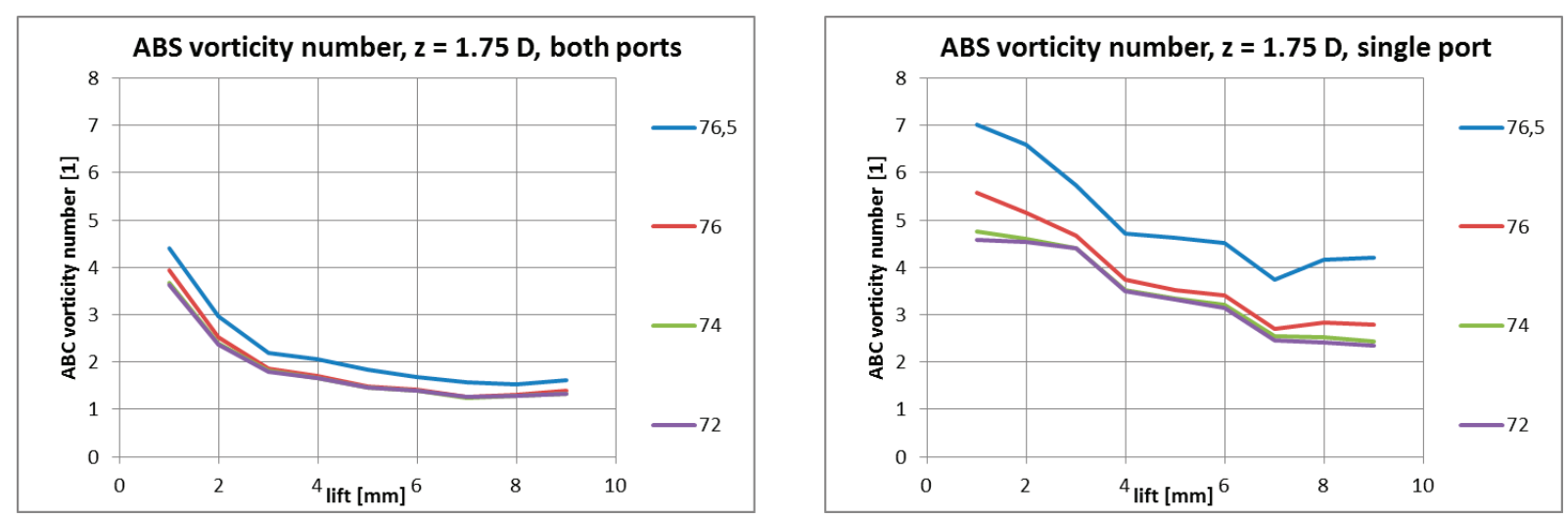

FIGURE 9: ABS swirl vorticity number - dependence on valve lift and max. diameter of evaluation area - the case with both open intake valves is on the left, the case with single open valve is on the right.

OBRÁZEK 9: ABS viŕivostní číslo - závislost na zdvihu ventilu a max. průměru vyhodnocovací oblasti - varianta se dvěma otevřenými sacími ventily vlevo, s jedním otevřeným ventilem vpravo.
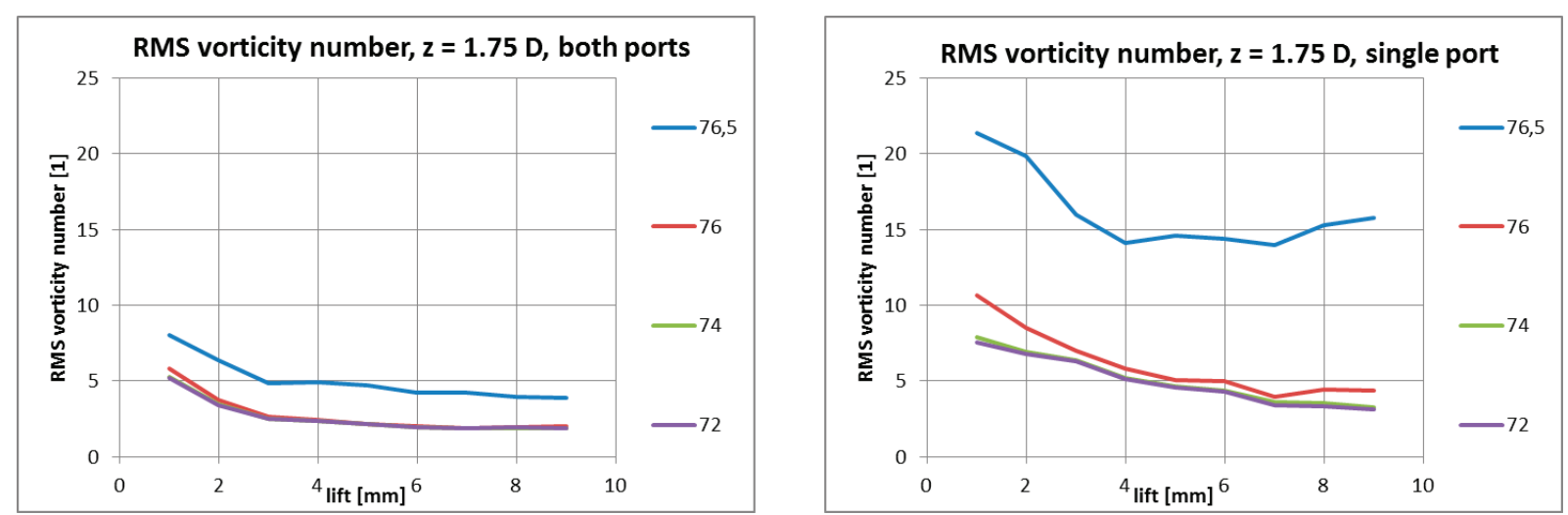

FIGURE 10: RMS swirl vorticity number - dependence on valve lift and max. diameter of evaluation area - the case with both open intake valves is on the left, the case with single open valve is on the right.

OBRÁZEK 10: RMS viŕivostní číslo - závislost na zdvihu ventilu a max. průměru vyhodnocovací oblasti - varianta se dvěma otevřenými sacími ventily vlevo, s jedním otevřeným ventilem vpravo. 


\section{ACKNOWLEDGEMENTS}

This research has been realized using the support of Technological Agency, Czech Republic, programme Centres of Competence, project TE01020020: 'Josef Božek Competence Centre for Automotive Industry'.

This research has been realized using the support of EU Regional Development Fund in OP R\&D for Innovations (OP VaVpl) and The Ministry of Education, Youth and Sports, Czech Republic, project CZ.1.05/2.1.00/03.0125: 'Acquisition of Technology for Vehicle Center of Sustainable Mobility'.

This research has been realized using the support of The Ministry of Education, Youth and Sports program NPU I (LO), project L01311: 'Development of Vehicle Centre of Sustainable Mobility'. All the help has been gratefully appreciated.

\section{LIST OF NOTATIONS AND ABBREVIATIONS}

$\begin{array}{ll}\text { AVG } & \text { average } \\ \text { ABS } & \text { absolute } \\ \text { RMS } & \text { root mean square } \\ \text { CTU } & \text { Czech Technical University in Prague } \\ \text { CFD } & \text { Computation Fluid Dynamics } \\ \text { ICE } & \text { Internal Combustion Engine } \\ \text { PANS } & \text { Partially Averaged Navier-Stokes (equation set) } \\ \text { LDA } & \text { Laser Doppler Anemometry } \\ \text { PIV } & \text { Particle Image Velocimetry }\end{array}$

\section{REFERENCES}

[1] Hatschbach, P.: Měření rychlostního pole ve válci spalovacího motoru pomocí integrálních metod a laserové dopplerovské anemometrie, Praha: 1995, PhD Thesis. České vysoké učení technické v Praze, Fakulta strojní.

[2] [Jackson, N.S., Stokes, J., Sadler, M., Correlation of the combustion characteristics of spark ignition engines with the in-cylinder flow field characterised using PIV in a water analog rig, SAE paper 971637, 1997

[3] Jaffri, K. - Hascher, H.G. - Novak, M. - Lee, K. - Schock, H. - Bonne, M. - Keller, P. : Tumble and Swirl Quantification within a Motored Four-Valve SI Engine Cylinder Based on 3-D LDV Measurements, SAE 970792,1997

[4] Hatschbach, P.: Quantification of the Vortex Structure in an IC Engine (In Czech), In: Colloquium FLUID DYNAMICS 2004. Praha: AV ČR, Ústav termomechaniky, 2004. pp. 47-50. ISBN 80-85918-89-7.

[5] Huang, R.F., C.W. Huang, S.B. Chang, H.S. Yang, T.W. Lin and W.Y. Hsu (2005). Topological flow evolutions in cylinder of a motored engine during intake and compression stroke. Journal of Fluids and Structures 20, 105-127.

[6] Vitek 0., Tichanek R., Hatschbach P.: Application of LES, PANS and RANS to a Case of Intake Channel Steady Flow Test Bench, In: Journal of Middle European Construction and Design of Cars, Vol. 13, No. 3, 2015, pp. 14-23. ISSN W1214-0821

[7] AVL AST (2013). FIRE Manual v2013, AVL List GmbH, Graz. 